\title{
EVALUATION OF SULPHUR CONTENT IN DIFFERENT ENERGY CROPS
}

\author{
Liena Poisa, Skaidrite Bumane ${ }^{1}$, Edgars Cubars ${ }^{2}$, Rasma Platace ${ }^{3}$ \\ ${ }^{1}$ Latvian Plant Protection Research Centre; ${ }^{2}$ Rezekne Academy of Technologies, Latvia; \\ ${ }^{3}$ Latvia University of Agriculture \\ lienapoisa@inbox.lv, skaidrite.bumane@laapc.lv, edgars.cubars@inbox.lv, rasmins@inbox.lv
}

\begin{abstract}
Within the territory of Latvia, grass biomass currently is considered to be one of the alternative sources for pellet production in the Baltic region and Northern Europe. The examined energy crops are characteristic with the persistence to the local climatic conditions and high biomass yield from 1 ha. The field trial was carried out during 2011-2013 in the research and study farm "Pēterlauki" (56 $\left.53^{\circ} \mathrm{N}, 2^{\circ} 71^{\prime} \mathrm{E}\right)$ of the Latvia University of Agriculture, in sod calcareous soils $\mathrm{pH} \mathrm{KCl} \mathrm{6.7,} \mathrm{containing} \mathrm{available} \mathrm{for} \mathrm{plants}$ $\mathrm{P}-52 \mathrm{mg} \cdot \mathrm{kg}^{-1}, \mathrm{~K}-128 \mathrm{mg} \cdot \mathrm{kg}^{-1}$, organic matter content 21 to $25 \mathrm{~g} \cdot \mathrm{kg}^{-1}$ in the soil. The field test fertiliser norms applied were the following $\left(\mathrm{kg} \mathrm{ha}^{-1}\right): \mathrm{N}_{0} \mathrm{P}_{0} \mathrm{~K}_{0}$ (control), $\mathrm{P}_{2} \mathrm{O}_{5}-80, \mathrm{~K}_{2} 0-120$ ( F - background), $\mathrm{F}+\mathrm{N}_{30}, \mathrm{~F}+\mathrm{N}_{60}$, $\mathrm{F}+\mathrm{N}_{90}$. Research objects: reed canary grass (Phalaris arundinacea L.), festulolium $(\times$ Festulolium Asch. \& Graebn.), tall fescue (Festuca arundinacea Schreb.) and timothy (Phleum pratense L.) are perennials yielding for $8-10$ years, plant length up to $1.5 \mathrm{~m}$. The sulphur content in the energy crops was $0.10 \pm 0.01 \%$. The sulphur content in reed canary grass, festulolium, tall fescue and timothy was dependent $(p<0.005)$ on the growing year and the nitrogen fertilizer rate, and on the interaction between the growing year and nitrogen additional fertiliser contribution amount. That means that the air temperature and the amount of precipitation during the plant growth period are of great importance.
\end{abstract}

Keywords: sulphur content, grass pellets sulphur content.

\section{Introduction}

Sulphur (S), just like chlorine, composes mainly gaseous SO2 and alkali and alkaline earth sulphates, which promotes corrosion of heating boiler elements [1] and contributes to emissions of sulphur dioxide into the atmosphere, the ratio of sulphur in herbaceous biomass usually is $0.1-0.2 \%$.

However, the researchers I. Obernberger, T. Brunner, G. Bärnthaler (2006) showed that 40-70\% of sulphur found in the biomass fuel turned into ashes and the rest - into gas (aerosols and $\mathrm{SO}_{2}$ ). The researchers also note that the concentration of $\mathrm{S}$, which is higher than $0.1 \%$ (dry matter), may cause corrosion problems, like too high levels of $\mathrm{Cl}$. It has been found that the $\mathrm{S}$ ratio, which exceeds $0.2 \%$ (dry matter), can lead to the emissions of $\mathrm{SO}_{\mathrm{x}}$.

The highest sulphur concentration is in straw. $\mathrm{Cl}$ and $\mathrm{S}$ in biomass are in the form of organic particles, but for the most part as the inorganic salts. Most of these substances are released during the combustion of carbon [2;3]. The emissions of $\mathrm{NO}_{\mathrm{x}}$ and $\mathrm{SO}_{\mathrm{x}}$, which are nitrogen or sulphur compounds, contribute to greenhouse gas emissions or acidification. There is almost no sulphur in wood $(0.02-0.06 \%)$. The sulphur content in peat is $0.1-0.4 \%, \mathrm{~S}$ in Latvian peat is $0.3 \%$, if the ash content is $5 \%$, and $\mathrm{S}$ is $0.5 \%$, if the ash content in peat is $10 \%$. The sulphur content in biomass is insignificant - from $0.02 \%$ to $2 \%$ [4]. Increased amount of sulphur in fuel contributes to the emission of sulphur dioxide into the atmosphere.

Sulphur oxides are a result of full sulphur fuel oxidation. Sulphur composes mainly $\mathrm{SO}_{2}(>95 \%)$ and $\mathrm{SO}_{3}$ emissions $(<5 \%)$, which are generated at low temperatures. Sulphur is not converted completely into $\mathrm{SO}_{\mathrm{x}}$ emissions, a lot of it stays in ash (40-90\%), while the smallest part of it in low temperatures is emitted in the form of $\mathrm{K}_{2} \mathrm{SO}_{4}$ or $\mathrm{H}_{2} \mathrm{~S}$.

In a heating boiler, where the flue gas is rapidly cooled, sulphates condense on fly ash particles or pipe surface [2;3]. Sulphur is an unwanted and harmful fuel component [4]. The main sources of sulphur dioxide $\mathrm{SO}_{2}$ in Latvia are so-called stationary sources of emissions - power objects.

The aim of the research: to evaluate the sulphur content in different energy crops.

\section{Materials and methods}

Field trial research objects: reed canary grass (Phalaris arundinacea L.), festulolium $(\times$ Festulolium Asch. \& Graebn.), tall fescue (Festuca arundinacea Schreb.), and timothy (Phleum pratense L.). The trial was carried out in 2011-2013 in the research and study farm "Pēterlauki" $\left(56^{\circ} 53^{\prime} \mathrm{N}, 23^{\circ} 71^{\prime} \mathrm{E}\right)$ of the Latvia University of Agriculture. The soil properties were as follows: sod 
calcareous soils $\mathrm{pH} \mathrm{KCl} 6.7, \mathrm{P}-152 \mathrm{mg} \cdot \mathrm{kg}^{-1}, \mathrm{~K}-128 \mathrm{mg} \cdot \mathrm{kg}^{-1}$, and organic matter content 21 to $25 \mathrm{~g} \cdot \mathrm{kg}^{-1}$ in the soil. The fertilizer rates applied in the research are summarised in Table 1.

Table 1

Fertilizer rates and symbols used in the text

\begin{tabular}{|c|c|c|}
\hline No. & Fertilizer $\left(\mathrm{kg} \cdot \mathrm{ha}^{-1}\right)$ & Symbol in the text \\
\hline 1. & NOP0K0 (control) & $\mathrm{a}$ \\
\hline 2. & $\mathrm{P}_{2} \mathrm{O}_{5}-80 ; \mathrm{K}_{2} 0-120$ (background) $(\mathrm{F})$ & $\mathrm{b}$ \\
\hline 3. & $\mathrm{~F}+\mathrm{N} 30$ & $\mathrm{c}$ \\
\hline 4. & $\mathrm{~F}+\mathrm{N} 60$ & $\mathrm{~d}$ \\
\hline 5. & $\mathrm{~F}+\mathrm{N} 90$ & $\mathrm{e}$ \\
\hline
\end{tabular}

The sulphur (S) content in various samples was determined in the accredited Laboratory of Agronomic Analysis of the Latvia University of Agriculture, using the analyser "Eltra CS-500 Analizator", and in compliance with the standard LVS EN ISO 5983-2:2009.

The grass biomass yield in 2012 and 2013 has been calculated from sward. Grass plant $\left(16 \mathrm{~m}^{2}\right)$ biomass samples, weighed with an accuracy of $\pm 0.01 \mathrm{~kg}$, were taken in three repeats from each fertilizer variant. The samples were applied for the identification of the dry matter. The dry matter of the yield was determined by drying the sample in the temperature of $105^{\circ} \mathrm{C}$ to constant weight (ISO 6496). The obtained results were recalculated per hectare $\left(\mathrm{t} \cdot \mathrm{ha}^{-1}\right)$.

The obtained results are statistically processed, applying descriptive and variation statistics, dispersion analysis and correlation analysis methods, Microsoft Excel and SPSS programme package (Arhipova, Bāliņa, 2006). Graphical images and tables are created in the above mentioned programmes.

Three-factor dispersion analysis is applied for the repetitions in order to assess the agrometeorological conditions (factor A), species (factor B), the nitrogen fertilizer norm amounts (factor $\mathrm{C}$ ) and the interaction of these factors, as well as the significance of the factor influence on the energy crop yield capacity and the sulphur content variability.

Applying two-factor and three-factor analysis, the assessment of the significance of the factors' interaction $\left(\eta^{2}, \%\right)$ is included in the calculation model. For the assessment of the significance of the factors' influence, two significance levels are used: $* p<0.05$ and $* * p<0.001$. [5]

Insufficient humidity (hydrotermical coefficient HTC <1) was observed in April 2011-2013, providing favourable conditions for soil preparation for sowing, but promoting uneven germination and revegetation of plants. Excessive humidity (HTC $>2)$ was in June (2011 and 2012) and September (2013). The optimal humidity $(1<\mathrm{HTC}<2)$ rate has been observed in 2012.

\section{Results and discussion}

Using the nitrogen norm $\mathrm{N}_{60}$, reed canary grass has been determined to have the largest fluctuations in the sulphur content. It shows ambiguous yet significant influence of nitrogen fertilizer (Fig. 1). It is specified in the standard EN 14961 for wood pellets that the maximum allowed sulphur content is $0.1 \%$ [6]. The average sulphur content, determined in the present research in both sowing years for all the species, is $0.1 \%$, which conforms to the standard EN 14961. It is stated in the research, carried out by the derived public entity "State Stende Cereals Breeding Institute", that the species do not vary in the sulphur in cereal grains $(0.23-0.32 \%)$ [7].

In 2012, the sulphur content in all four species was $<0.1 \%$, but in 2013 it was $>0.1 \%$. The sulphur content closest to the requirements of the standard EN 14961 in both yield years (2012 and 2013) on average has been determined in the dry matter of tall fescue $(0.098 \pm 0.01 \%)$ and festulolium $(0.099 \pm 0.01 \%$ ) (Fig. 1$)$, yet the sulphur content in reed canary grass $-0.106 \pm 0.01 \%$ and timothy $-0.101 \pm 0.01 \%$ was also very close to the standard.

Assessing the effect of the growing year and the fertilizer norms on the sulphur content in grass plants, it is clear that the most significant differences are caused by the meteorological conditions during the vegetation period (Fig. 2). The researchers P. Kasal, P. Ruzek, H. Kusa, J. Cepl (2011) [8] have stated that the growing conditions of a specific year, including rainfall and temperature, have a 
strong influence on the fertilizer use efficiency. It means that the norm of nitrogen should be such as to ensure economically justified yield.

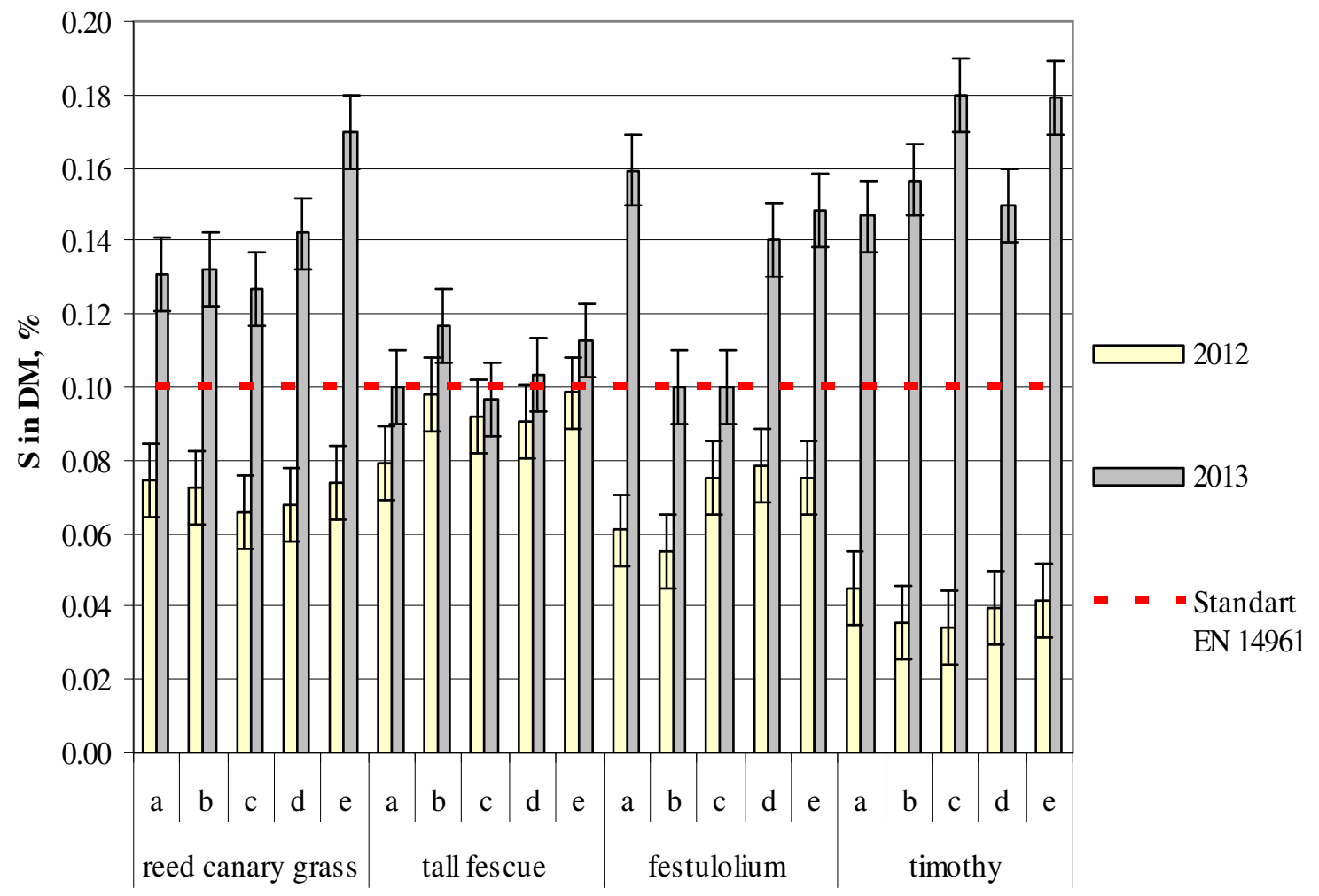

Fig. 1. Sulphur content in DM (dry matter) depending on energy crop species and $\mathbf{N}$ fertilizer rates: $\mathrm{a}-\mathrm{N}_{0} \mathrm{P}_{0} \mathrm{~K}_{0}$ (control); $\mathrm{b}-\mathrm{P}_{2} \mathrm{O}_{5}-80 ; \mathrm{K}_{2} \mathrm{O}-120$ (F - background); c $-\mathrm{F}+\mathrm{N} 30$;

$$
\mathrm{d}-\mathrm{F}+\mathrm{N} 60 ; \mathrm{e}-\mathrm{F}+\mathrm{N} 90
$$

Nitrogen fertilizer is one of the key determinants of the yield, which is confirmed by the scientific literature data on significant yield increase with the increase of the fertilizer norm [9-12]. The obtained amount of sulphur in kg per hectare depends on the yield capacity of grass plants and the sulphur content in dry matter (Fig.1, Fig.2): reed canary grass - 648.1 $\pm 124.7 \mathrm{~kg} \cdot \mathrm{ha}^{-1}$, tall fescue $623.7 \pm 124.7 \mathrm{~kg} \cdot \mathrm{ha}^{-1}$, festulolium $-588.1 \pm 124.7 \mathrm{~kg} \cdot \mathrm{ha}^{-1}$ and timothy $603.7 \pm 124.7 \mathrm{~kg} \cdot \mathrm{ha}^{-1}$.

By increasing the norm of nitrogen fertilizers on grass plants, the total amount of sulphur per hectare in both cultivation years increases as well (Fig. 2). As with the higher fertilizer norms the nitrogen fertilizer use coefficient reduces, there is a risk that unused nitrogen compounds might pollute the environment or be delivered to water reservoirs in rainfall [13]. Large fertilizer norms should not be used on reed canary grass, as it can promote the reed canary grass, which prefers wet soil, becoming an invasive variety in wildlife biotopes [14].

In order to assess the influence of grass plant species as a factor, a three-factor dispersion analysis has been carried out. After the identification of the influence of meteorological conditions in the growing year $\left(F_{A}\right)$, the proportion of grass plant species $\left(F_{B}\right)$ and the nitrogen fertilizer norm $\left(F_{C}\right)$ factors' influence, it has been found that a significant data variation is ensured by the factor $A$ $(\eta=41.6 \%$ and $\eta=66.9 \%)(p<0.001)$ and the nitrogen fertilizer norm $(\eta=30.1 \%$ and $\eta=2.2 \%)$ $(p<0.05)$, as well as the interaction of the factors.

Other studies also indicate that the yield capacity of energy crops depends significantly on the norm of fertilizer, plant species and harvesting time [15].

The Finnish researchers K. Hakala, M. Kontturi and K. Pahkala (2009) [16] claim that the capacity of yield is affected by the local climatic conditions. The LLU researchers A. Liniņa, A. Ruža (2008) [17] have stated that "the efficiency of nitrogen fertilizer in total and its separate rations on different species, regarding the vegetative length and intensity, is highly dependent on the meteorological situation during the vegetation period". The analysis of the effects of factors' 
interaction shows the reaction of different species towards the increase of the nitrogen fertilizer norm [15].

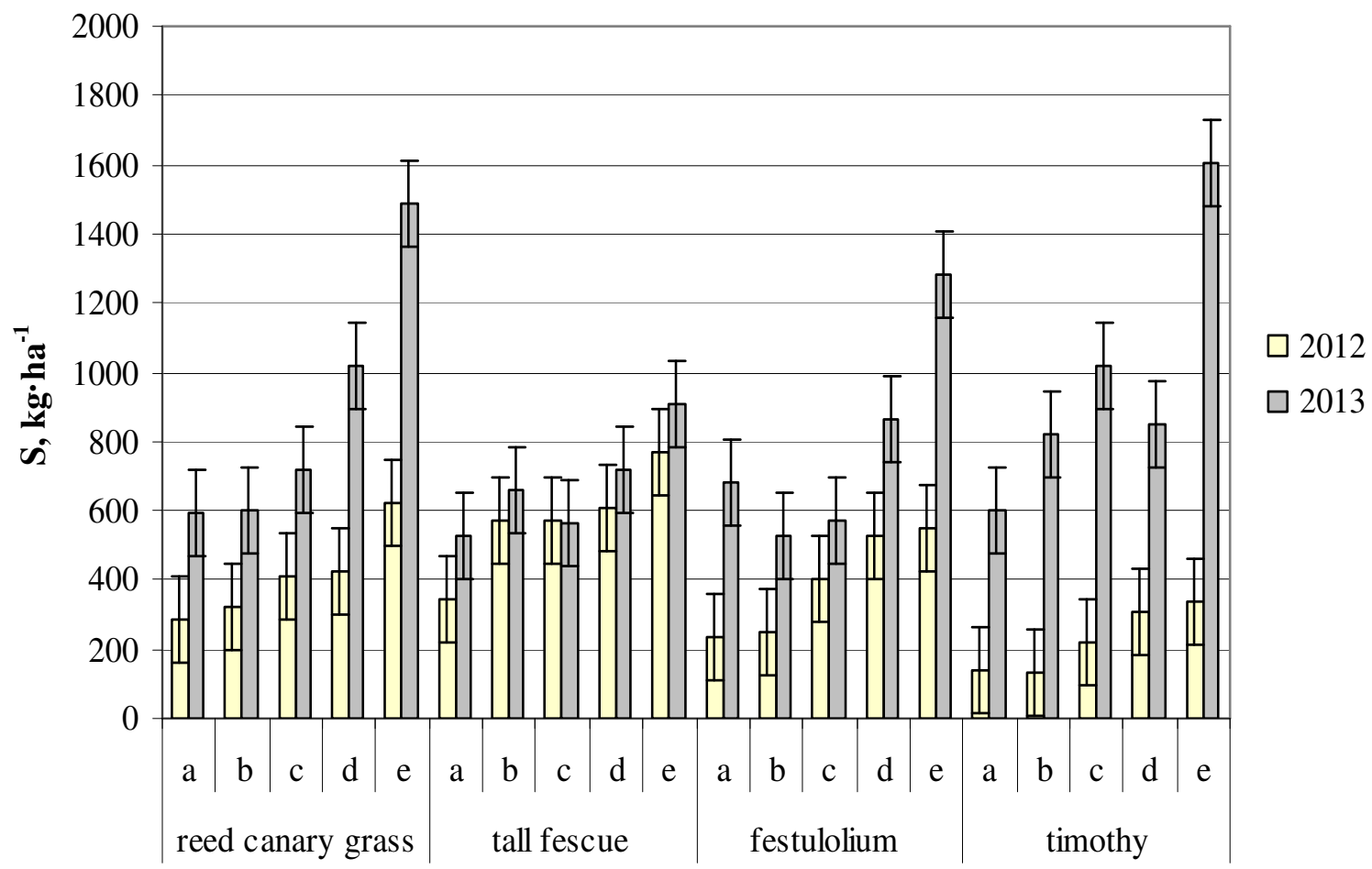

Fig. 2. Sulphur content in yield of hectare depending on energy crop species and $\mathbf{N}$ fertilizer rates: $\mathrm{a}-\mathrm{N}_{0} \mathrm{P}_{0} \mathrm{~K}_{0}$ (control); $\mathrm{b}-\mathrm{P}_{2} \mathrm{O}_{5}-80 ; \mathrm{K}_{2} \mathrm{O}-120(\mathrm{~F}-$ background); $\mathrm{c}-\mathrm{F}+\mathrm{N} 30$; $\mathrm{d}-\mathrm{F}+\mathrm{N} 60 ; \mathrm{e}-\mathrm{F}+\mathrm{N} 90$

Table 2

Influencing factor proportion on the energy crop quality parameter, $\eta, \%$

\begin{tabular}{|l|c|c|}
\hline \multirow{2}{*}{\multicolumn{1}{|c|}{ Factors }} & \multicolumn{2}{|c|}{ Sulphur } \\
\cline { 2 - 3 } & $\mathrm{S}, \mathrm{kg} \cdot \mathrm{ha}^{-1}$ & $\mathrm{~S}$ in DM,$\%$ \\
\hline Growing year $(A)$ & $41.3^{* *}$ & $66.9^{* *}$ \\
\hline Energy crop species $(B)$ & $\mathrm{ns}$ & $\mathrm{ns}$ \\
\hline N fertilizer rate $(C)$ & $30.1^{* *}$ & $2.2^{*}$ \\
\hline Interaction $(A \times B)$ & $11.9^{* *}$ & $22.4^{* *}$ \\
\hline Interaction $(A \times C)$ & $6.0^{*}$ & $\mathrm{~ns}$ \\
\hline Interaction $(B \times C)$ & $3.0^{*}$ & $3.2^{*}$ \\
\hline Interaction $(A \times B \times C)$ & $3.8^{*}$ & $3.4^{*}$ \\
\hline Effect of unexplored factors & $\mathrm{ns}$ & $\mathrm{ns}$ \\
\hline
\end{tabular}

* significant at the 0.05 level $\left(F_{\text {fakt }}>F_{0.05}\right) ; * *$ significant at the 0.001 level $\left(F_{\text {fakt }}>F_{0.05}\right) ; n s-$ non-significant at the 0.05 level $\left(F_{\text {fakt }}<F_{0.05}\right)$

\section{Conclusions}

1. The average sulphur content in dry matter of the energy crops examined in the research - tall fescue, festulolium, reed canary grass and timothy was $0.1 \% \pm 0.01 \%$, while the sulphur content closest to the requirements of the standard EN 14961 in both yield years (2012 and 2013) on average has been determined in the dry matter of tall fescue $(0.098 \pm 0.01 \%)$ and festulolium $(0.099 \pm 0.01 \%)$.

2. The amount of sulphur in $\mathrm{kg}$ per hectare depends on the yield capacity of energy crops and the sulphur content in dry matter: reed canary grass - $648.1 \pm 124.7 \mathrm{~kg} \cdot \mathrm{ha}^{-1}$, tall fescue $623.7 \pm 124.7 \mathrm{~kg} \cdot \mathrm{ha}^{-1}$, festulolium $-588.1 \pm 124.7 \mathrm{~kg} \cdot \mathrm{ha}^{-1}$ and timothy $603.7 \pm 124.7 \mathrm{~kg} \cdot \mathrm{ha}^{-1}$, the higher is the yield capacity, the higher is the sulphur fertility. 
3. The sulphur content and amount in $\mathrm{kg}$ per ha is significantly $(p<0.05)$ affected by the meteorological conditions in a growing year and nitrogen fertilizer, as well as the interaction of several factors.

\section{References}

1. Obernberger I., Brunner T., Barnthaler G. Chemical properties of solid biofuels - significance and impact. Biomass and Bioenergy, no. 30, 2006. pp. 973-982.

2. Van Loo S., Koppejan J. The Handbook of Biomass Combustion \& Co-firing. UK: CPI Antony Rowe, 2008. 442 p.

3. Williams A., Jones J.M., Ma L., Pourkashanian M. Pollutants from the combustion of solid biomass fuels. Progress in Energy and Combustion Science. Progress in Energy and Combustion Science, no. 38, 2012. pp. 113-137.

4. Cars A. Energoresursi (Energy resource). Rīga: SIA Baltic Communication Partners, 2008. 102 p. (In Latvian)

5. Arhipova I., Bāliņa S. Statistika ekonomikā (Statistical economic). Rīga: Datorzinību centrs, 2006. 352 p. (In Latvian)

6. Alakangas E. European Standard (EN 14961) for Wood Chips and Hog Fuel. Forest Bioenergy 2010, $31^{\text {st }}$ August $-3^{\text {rd }}$ September 2010, Book of proceedings. FINBIO Publications 47, 2010, pp. 329-340.

7. Belicka I., Miglāne V., Jansone Z. Vasarāju graudaugu sugu piemērotība siltumenergijas ražošanai. Proceedings of the 7th International Scientific and Practical Conference "Enviroment. Technology. Resources", June 25-27, 2009, Rezekne, Latvia, vol. 1, 2009, pp. 24-31.

8. Kasal P., Ruzek P., Kusa H., Cepl J. Effective ways of mineral nitrogen fertilizer applications and their effect on nitrogen use by potatoes, yield and potato quality. Abstracts of the $18^{\text {th }}$ Triennial Conference of the European Association for Potato Research. Ed. by J. Santala and J. P. T. Valkonen, 2011, $151 \mathrm{p}$.

9. Iványi I., Izsáki Z. The Influence of nutrient supply and plant density on the yield of fibre hemp. 3th International Symposium Bioresource Hemp 2000 \& other fibre crops. September 13 - 16, 2000, Wolfsburg, Germany, pp. 1-18.

10. Schäfer T. The Influence of Growing Factors and Plant Cultivations Methods on Biomass and Fibre Yield as Well as on Fibre Quality of Hemp (Cannabis sativa L.). Journal of Natural Fibers, vol. 2, no 1, 2005. pp. 1-14.

11. Komárek P., Nerušil P., Kohoutek A., Odstrčilová V. The effect of repeated direct sowing of grass - legume seed mixtures into grasslands on forage production and quality. Grassland Science in Europe, vol. 12, 2007. pp. 39-42.

12. Kumi - Boateng B., Yakubu I. Predicting the Yield of Crops Using Gis/Gps Integration - A Case Study at Benso Oil Palm Plantation Limited. European Journal of Scientific Research, vol. 42, no. 2, 2010. pp. 314-325.

13. Skrabule I., Vaivode A., Ruža A. Slāpekḷa mēslojuma normu ietekme uz barības vielu izmantošanās rādītajiem kartupel̦iem (The Impact of Nitrogen Fertilizer Norm on the Indicators of Nutrient Use for Spring Barley). International Scientific and Practical Conference "Zinātne Latvijas lauksaimniecības nākotnei: pārtika, lopbarība, škiedra un enerǵija raksti” February 23 24, 2012, Jelgava, Latvia. Jelgava: LLU, 2012. pp. 90-94.

14. Lyons K. E. Element Stewardship Abstract for Phalaris arundinacea L. Reed canarygrass. Ed. by J. M. Randall, M. Robison, T. L. Morisawa, B. Meyers - Rice, 1998. [online] [09.09.2012]. Available at: http://www.imapinvasives.org/GIST/ESA/esapages/documnts/phalaru.pdf

15. Gutmane I., Adamovich A. Analysis Of Sward Management Factors Influencing Festulolium and Lolium x boucheanum Yield Formation. Agronomijas vēstis (Latvian Journal of Agronomy), no. 10, 2008, pp. 117-122.

16. Hakala K., Kontturi M., Pahkala K. Field biomass as global energy source. Agricultural and Food Science, vol. 18, no. 3-4, 2009. pp. 347-365.

17. Liniņa A., Ruža A. (2008) Agroekolog̣isko apstākḷu ietekme uz ziemas kviešu graudu lipekḷa saturu un tā kvalitātes rādītājiem (Influence of agroecological conditions on winter wheat grain gluten quantity and quality indices). Agronomijas Vēstis (Latvian Journal of Agronomy), no. 10, 2008. pp. 145-151. (In Latvian) 